\title{
CHANGES IN SEASONALLY MINERAL CONTENT OF Calligonum polygonoides L. SHRUB AND ITS CAPACITY OF MEETING DAILY MINERAL REQUIREMENTS OF GRAZING SMALL RUMINANT
}

\author{
Suleyman TEMEL \\ Igdir University, Faculty of Agriculture, Department of Field Crops, Igdir, TURKEY \\ Corresponding author: stemel33@hotmail.com
}

Received: 01.08.2019

\begin{abstract}
Phog (Calligonum polygonoides $\mathbf{L}$.) is widely grown in arid Igdir-Aralık wind erosion site and is an alternative feed source for grazing small ruminant (sheep and goat) in terms of its yield and quality. However, there are no studies on the mineral content during the plant's active growth period. Our aim is to determine the macro and micro mineral contents during plant's development and to check whether it meets with the daily mineral requirements of small ruminant. The research was carried out in a protected-area in 2016 and 2017. Samples were taken from 20 selected shrub clusters for 7 months (April-October) at the $15^{\text {th }}$ of each month. Results showed that mineral contents (except copper, zinc and manganese) differs as to months and phosphorus, potassium, calcium, magnesium, sodium, iron, copper, zinc and manganese contents ranged between 0.330.63\%, 1.45-2.03\%, 1.32-1.81\%, 0.65-0.99\%, 0.20-0.30\%, 99.73-190.43 ppm, 2.00-2.67 ppm, 24.77-31.83 ppm and 34.16-45.56 ppm, respectively. According to these findings, phosphorus, potassium, calcium, sodium, iron, zinc and manganese contents of plant can sufficiently meet the daily requirements of small ruminant while copper content is not enough for the daily requirement. On the other hand, magnesium content was detected to be higher than the recommended level.
\end{abstract}

Keywords: Phog, Grazing ruminants, Macro-micro minerals, Wind erosion area

\section{INTRODUCTION}

Survival and healthy development of animals not only depend on nutrients such as protein, fat, carbohydrates and vitamins but also on a healthy supply of minerals. Thus, it is important to meet mineral matter requirements of animals as well as proper feeding. Minerals, which are very important for all live organisms, have an important role in boosting rumen activities and increasing the efficiency of feed usage in ruminants (Spears, 1994). Furthermore, minerals connect with proteins, lipids and other matters to form soft and hard tissues of the body and have a specific effect on osmotic pressure, achievement of acid-base balance, and stimulation of nerve and muscle systems by conjoining the structure of enzyme and hormone systems (Eren, 2009). Thus, a lack or an excess of minerals in animal feeds or insufficient or excessive intake of minerals by animals may have adverse effects on reproductive, developmental and immunity systems of animals as well as on their productivity (McDowell, 1992; Altıntas, 2013).

Mineral substances that have an important role in the metabolic activities of animals cannot be synthesized in the animal body (Kutlu et al., 2005) and animal intake the minerals they need mostly from the plants which they are grazed (Gokkus et al., 2013). However, the chemical composition of the plants and the plant communities in the pastures vary according to species, soil type, climate, phenological period and abiotic factors (Greene et al., 1987; Underwood and Suttle, 1999). For instance, Ca, P, $\mathrm{K}, \mathrm{Fe}$ and $\mathrm{Cu}$ contents of plants grown in the pastures were reported to be high in spring, and $\mathrm{Zn}$ and $\mathrm{Mn}$ contents were reported to be high in autumn. Therefore, nutrient deficiencies occur in animals fed with these plants during periods when the mineral content of pasture plants is low (Gokkus et al., 2013). The ability of plants to accumulate mineral substances within their bodies depends on the development period of the plant, nutrient content, root structure, the structure of the soil in the area where the plant grows and its mineral matter content, and the amount and distribution of precipitation in the vegetation period (Mandal, 1997; Chetri et al., 1999; Abdullah et al., 2013; Temel et al., 2016; Temel and Surmen, 2018; Temel, 2019). On the other hand, the daily nutritional requirements change according to the physiological functions of grazing animals, and therefore the development period, pregnancy and lactation periods of animals play an important role in determining the daily nutritional requirements (Cook and Harris, 1977). Thus, it is important to know the mineral properties of the plants 
used as feed sources, as well as their quality characteristics, for determining the amount and content of mineral substances that animals will consume from the feeds (Keskin et al., 2016).

In the arid and saline areas where extreme climate and soil conditions prevail, many domestic plants cannot develop, and they cannot provide feed production with proper quality and at sufficient quantities. However, shrub and woody plants that are developed under natural ecological conditions due to their strong and deep root systems can easily grow in areas where many domestic plants are not grown, and provide a significant feed source for grazing ruminants (Temel and Tan, 2011; Tan and Temel, 2012; Dokulgen and Temel, 2015; Temel and Kir, 2015; Aygun et al., 2018). In addition, since quality losses in these species occur slower and at lower amounts compared to the herbaceous species, they can produce feeds for animals that have high energy and nutritional content and which are rich in vitamins and minerals (Ahmad et al., 2008; Ghazanfar et al., 2011; Tan and Temel, 2012; Temel et al., 2015; Temel and Surmen, 2018; Temel, 2019). Thus, the shrubs that can adapt to such areas are considered as an advantage in supplying the quality coarse fodder required by ruminants as well as for meeting their mineral needs.

One of the species belonging to Calligonum genius, which are distribute in deserts (in North Africa, West and Mid Asia and Southern Europe) in arid and semi-arid areas of the world, is phog (Calligonum polygonoides $\mathrm{L}$. ssp. comosum (L'Hér.)) (Brandbyge, 1993; Kerven et al., 2004; Abdurahman et al., 2012; Govind et al., 2012), as it is known in Turkey and it grows naturally only in IgdirAralik wind erosion site of the country. Besides its important functions in keeping sand dunes, erosion control and enhancing soil fertility (Gyssels et al., 2005; De Baets et al., 2006; Artan and Temel, 2018), underground and surface parts of the plant may also be used as human food, firewood and for medical purposes (Liu et al., 2001; Gehlot, 2006; Abdurahman et al., 2012; Abdullah et al., 2013; Temel and Temel, 2018). In addition to all these properties, shoots of phog are preferred as an alternative feed source in animal nutrition due to their high nutritional content (Oktay and Temel, 2015a) and its shoots are grazed intensively by animals (Temel and Temel, 2018). It is a significant feed source for small ruminant that are grazed especially during summer and autumn periods due to its sustaining of shoot development and greenness during vegetation (Oktay and Temel, 2015b). Despite such advantageous characteristics, there are no studies on determining macro and micro mineral content of phog during its active development stage to the best of our knowledge. There is only one study on determination of the mineral content of the plant in spring (February) period (Abdullah et al., 2013).

Thus, this study was conducted to determine the mineral matter content of phog (Calligonum polygonoides L. ssp. comosum (L'Hér.), which commonly grows on Igdir-Aralik wind erosion site under arid climate, during its vegetation period and to determine whether the plant sufficiently provides for the daily mineral requirements of grazing small ruminant.

\section{MATERIALS AND METHODS}

The research was carried out in Igdir-Aralik wind erosion site which is situated at $850 \mathrm{~m}$ of altitude in the Northeast of Turkey in 2016 and 2017. The region has the most arid climate in Turkey with an average long-year temperature of $13.4^{\circ} \mathrm{C}$, an annual precipitation amount of $214.4 \mathrm{~mm}$ and a relative humidity $60.8 \%$ (Table 1 ). Average temperature in 2016 and 2017 during which the research was conducted was measured as $12.8^{\circ} \mathrm{C}$ and 12.1 ${ }^{\circ} \mathrm{C}$, respectively, while annual precipitation was measured as $184.9 \mathrm{~mm}$ and $119.3 \mathrm{~mm}$, respectively and relative humidity as $64.3 \%$ and $65.0 \%$, respectively (Table 1) (Anonymous, 2018).

Table 1. Climate data for 2016-2017 and long year average of the region where the research was conducted

\begin{tabular}{llllllllll}
\hline & \multicolumn{3}{l}{ Temperature $\left({ }^{\circ} \mathbf{C}\right)$} & \multicolumn{3}{c}{ Precipitation $(\mathbf{m m})$} & \multicolumn{3}{c}{ Relative humidity $(\%)$} \\
\hline Months & LYA & $\mathbf{2 0 1 6}$ & $\mathbf{2 0 1 7}$ & LYA & $\mathbf{2 0 1 6}$ & $\mathbf{2 0 1 7}$ & LYA & $\mathbf{2 0 1 6}$ & $\mathbf{2 0 1 7}$ \\
\hline January & -3.5 & -1.7 & -8.6 & 3.1 & 13.1 & 3.6 & 75.2 & 84.8 & 94.2 \\
February & 3.3 & 3.6 & -8.4 & 1.7 & 17.7 & 3.6 & 67.7 & 83.5 & 91.7 \\
March & 8.7 & 8.6 & 6.3 & 29.4 & 7.1 & 8.4 & 56.1 & 60.1 & 71.9 \\
April & 14.5 & 14.4 & 13.3 & 34.5 & 21.7 & 13.2 & 54.2 & 55.9 & 55.0 \\
May & 18.7 & 18.5 & 18.9 & 55.0 & 21.8 & 33.3 & 60.1 & 61.5 & 58.8 \\
June & 23.9 & 23.0 & 24.4 & 18.4 & 32.9 & 4.8 & 46.7 & 53.1 & 43.3 \\
July & 27.6 & 27.4 & 28.4 & 3.7 & 0.2 & 0.3 & 41.6 & 42.9 & 40.9 \\
August & 26.7 & 27.7 & 28.0 & 5.8 & 7.3 & 3.9 & 44.0 & 42.9 & 43.6 \\
September & 22.2 & 20.3 & 23.1 & 8.5 & 7.5 & 0.2 & 49.6 & 51.5 & 46.2 \\
October & 13.2 & 12.2 & 12.4 & 31.1 & 20.7 & 17.4 & 70.5 & 72.5 & 70.4 \\
November & 6.2 & 2.9 & 6.7 & 18.3 & 29.0 & 27.2 & 78.8 & 79.9 & 82.4 \\
December & -1.4 & -3.8 & 0.7 & 4.9 & 5.9 & 3.4 & 85.6 & 83.1 & 81.7 \\
\hline Average/Total & 13.4 & 12.8 & 12.1 & 214.4 & 184.9 & 119.3 & 60.8 & 64.3 & 65.0 \\
\hline
\end{tabular}

LYA: Long year average

When the soil properties of the research area were examined, it was seen that the soil is non-saline (EC: 1.79 $\left.\mathrm{dS} \mathrm{m}^{-1}\right)$, medium alkaline ( $\mathrm{pH}:$ 7.92) and limey $(9.11 \%)$, poor in terms of organic matters $(0.18 \%)$, with low nitrogen $(0.009 \%)$ and phosphorus $(2.19 \mathrm{ppm})$ amounts and a high potassium $(0.35 \%)$ content (Kacar, 1972). In 
this region where extreme climate and soil conditions are experienced, the dominant vegetation is composed of xerophyte herbaceous and shrub species. One of these species is phog (Calligonum polygonoides L. ssp. comosum (L'Hér.) shrub which is used as plant material in the present study. Phog, a member of Polygonaceae family is a perennial species that grows thin shoots throughout its active development period.

The research was established in an area where phog grows intensively and not grazed by animals. A total of 20 shrub clusters of similar size were selected from the designated area, and samples were taken from 20 selected shrub clusters for 7 months (April-October) at the $15^{\text {th }}$ of each month, by simulating grazing habits of the animals. Feed samples were first dried in the open air and then in a drying oven set at $105{ }^{\circ} \mathrm{C}$ until their weights are fixed. After this, the samples were ground in a laboratory-type grinder. To determine phosphorus $(\mathrm{P})$, potassium $(\mathrm{K})$, calcium $(\mathrm{Ca})$, magnesium $(\mathrm{Mg})$, sodium $(\mathrm{Na})$, iron $(\mathrm{Fe})$, copper $(\mathrm{Cu})$, zinc $(\mathrm{Zn})$ and manganese $(\mathrm{Mn})$ amounts, the ground samples were subjected to wet decomposition in a microwave oven resistant to 40 bars of pressure using 2 units of nitric acid $\left(\mathrm{HNO}_{3}\right)$ and 3 units of hydrogen peroxide $\left(\mathrm{H}_{2} \mathrm{O}_{2}\right)$. Following wet decomposition, mineral contents were determined by reading in an ICP OES spectrophotometer (Inductively Couple Plasma - Optical Emission Spectrometry) device (Mertens, 2005a, Mertens, 2005b). Since nitrogen (N) content of the offshoot samples were reported in a previously-published study, this parameter is not included in the present study.

The data obtained from the study were subjected to variance analysis in SSPS statistical package software in accordance with the randomized block experiment design. The data from the two years were pooled as there were no significant differences between years and the significant averages were determined according to Duncan's Multiple Comparison Test.

\section{RESULTS AND DISCUSSION}

\section{Macro minerals}

The amount of macro-mineral matters contained in the phog (Calligonum polygonoides) plant in seven months from April to October is given in Table 2. It has been determined that there are significant changes in all macro mineral contents of the plant according to months. Phosphorus content of the plant changed by $0.33 \%$ to $0.63 \%$, while potassium, calcium, magnesium and sodium contents changed by $2.03 \%-1.45 \%, 1.32 \%-1.82 \%, 0.65 \%-$ $0.99 \%$ and $0.20 \%-0.30 \%$, respectively (Table 2 ).

Table 2. Macro mineral contents of Calligonum polygonoides by months

\begin{tabular}{lccccc}
\hline Months & P(\%) & Ca (\%) & K (\%) & Na (\%) & Mg (\%) \\
\hline April & $0.33 \mathrm{c}$ & $1.81 \mathrm{a}$ & $1.68 \mathrm{bc}$ & $0.30 \mathrm{a}$ & $0.99 \mathrm{a}$ \\
May & $0.49 \mathrm{~b}$ & $1.52 \mathrm{~b}$ & $1.83 \mathrm{ab}$ & $0.20 \mathrm{bc}$ & $0.87 \mathrm{ab}$ \\
June & $0.54 \mathrm{ab}$ & $1.49 \mathrm{~b}$ & $2.03 \mathrm{a}$ & $0.21 \mathrm{bc}$ & $0.82 \mathrm{bc}$ \\
July & $0.53 \mathrm{ab}$ & $1.33 \mathrm{~b}$ & $1.84 \mathrm{ab}$ & $0.24 \mathrm{bc}$ & $0.81 \mathrm{bc}$ \\
August & $0.63 \mathrm{a}$ & $1.37 \mathrm{~b}$ & $1.93 \mathrm{ab}$ & $0.22 \mathrm{bc}$ & $0.79 \mathrm{bc}$ \\
September & $0.59 \mathrm{ab}$ & $1.39 \mathrm{~b}$ & $1.98 \mathrm{ab}$ & $0.23 \mathrm{bc}$ & $0.74 \mathrm{bc}$ \\
October & $0.47 \mathrm{~b}$ & $1.32 \mathrm{~b}$ & $1.45 \mathrm{c}$ & $0.25 \mathrm{~b}$ & $0.65 \mathrm{c}$ \\
\hline Mean & 0.51 & 1.46 & 1.82 & 0.24 & 0.81 \\
\hline P value and Significant & $6.68^{* *}$ & $6.38^{* *}$ & $4.28^{* *}$ & $6.57 * *$ & $3.95^{*}$ \\
\hline
\end{tabular}

$\mathrm{a}, \mathrm{b}$ and $\mathrm{c}$ Different letters in the same column indicate significant differences in the macro mineral contents. $* * \mathrm{P}$ values are very significant at $1 \%$ probability level.

The highest phosphorus and potassium contents were detected in August and June, respectively, while the highest magnesium and sodium contents were measured in April. Varying macro mineral contents of the plant throughout its development period may be a result of changing climate conditions as to months. When the climate data of the region were examined (Table 1), phosphorus and potassium contents of the plant were low in summers when temperatures are high while calcium, magnesium and sodium were relatively higher in April than the other months, during when the temperatures are low. Indeed, it was reported that increases in soil and air temperature causes an increase in both phosphorus and potassium contents and a decrease in both calcium and magnesium contents (Hoveland and Monson, 1980; Kacar and Katkat, 1997). Moreover, scarcity of water, or drought, is thought to be another reason of the increase in potassium content during summers, as it was reported that increases in $\mathrm{K}$ contents of the plants are observed during times of possible droughts (Buxton and Fales, 1994). Furthermore, it was also reported that calcium and magnesium contents are found to be at the highest ratios at the beginning of the growth period (Vardar, 1983; Sher et al., 2012). Abdullah et al. (2013) reported $0.024 \%$ phosphorus, $0.34 \%$ potassium, $0.27 \%$ calcium, $0.017 \%$ magnesium and $0.22 \%$ sodium in phog samples taken in February. These results are quite lower than our findings in the present study. This may be stemming from the period within which the sampling carried out as well as from the differences in climatic and soil conditions of the trial area, since nutritional compositions of the plants may vary according to soil type, climate and developments stages (Greene et al., 1987).

Animal body contains approximately $1.0 \%$ of phosphorus and $1.5 \%$ calcium (Kutlu et al., 2005). Calcium and phosphorus are most widely found elements in the body and approximately $99 \%$ of calcium and $80 \%$ of phosphorus are within the bone and teeth structure. 
Bone formation weakens in the absence of these two elements and fragility of bones increases (NRC, 2001; McDonald et al., 2011; Kutlu et al., 2005). In addition, lack of appetite are seen in animals in the absence of phosphorus as well as decreases in fecundity and milk yield (NRC, 2001; Lambers et al., 2003; Kutlu et al., 2005; McDonald et al., 2011). Calcium is not only an essential component of liquids in living cells and tissues, but is also a necessary element for activation of many enzymes. Toxicity is a consequence of an overaccumulation of calcium in the animal body and in soft tissues in case animals fed with high calcium-content feeds (McDowell, 2000). The maximum tolerable levels of phosphorus and calcium in the feeds of small ruminant are determined as $0.6 \%$ and $1-2 \%$, respectively (NRC, 2005; ANAC, 2018). On the other hand, it was also stated that feeds should contain at least $0.4-0.7 \%$ phosphorus and $0.6-1.0 \%$ calcium in order to meet requirements of ruminants (NRC, 2001). According to the results of our research, phosphorus content of Calligonum polygonoides is at the recommended levels for the nutritional needs of small ruminant in all months of the plant's development period. Calcium content, on the other hand, is above the recommended level $(0.6-1.0 \%)$ for the nutrition of small ruminant; however, this does not in excess of the maximum amount that must be in the animals' daily diets.

Bodies of the animals contain approximately $0.2 \%$ potassium and $0.16 \%$ sodium (Kutlu et al., 2005). Potassium and sodium play important roles in the animal body, especially in reaching acid-base balance, regulating osmotic pressure, stimulating nerve and muscle systems, absorption of glucose and amino acids and carbohydrate metabolism. Symptoms of weakness occur in the absence of both minerals as well as a decline in growth and development of the animals (NRC, 2001; McDonald et al., 2011; Kutlu et al., 2005). Maximum tolerable levels of potassium and sodium in the diets of small ruminant are accepted as $2 \%$ and $4 \%$, respectively (NRC, 2005; ANAC, 2018). It is also reported that feeds must contain $0.65 \%$ potassium and $0.14-0.40 \%$ sodium to meet the daily requirements of ruminants (NRC, 2001). It is observed in our research that potassium and sodium contents of Calligonum polygonoides do not exceed their respective maximum tolerable levels and fall within the recommended levels for the nutrition of small ruminant in all months throughout the plant's development.

Another mineral, magnesium, is found in the animal body at proportion of $0.04 \%$ (Kutlu et al., 2005). Magnesium is in a close relationship with calcium and phosphorus. $70 \%$ of the magnesium in the animal body can be found in the skeletal structure while the remaining potion is in soft tissues and liquids. Magnesium phosphate plays an important role in activation of transferase enzymes, carbohydrate and lipid metabolism and cell respiration. Irritability, myotonia and nerval overextension, decreases in carbohydrate and lipid metabolism, weakness in skeletal and hoof development and decline in the growth and development of animals can be seen in case of a lack of magnesium in the animal diet (NRC, 2001; McDonald et al., 2011; Kutlu et al., 2005). Maximum tolerable level of magnesium in the diet of small ruminant is determined as $0.6 \%$ based on the weight of the mineral within the dry matter (NRC, 2005). On the other hand, it was also reported that feeds of small ruminant must contain at least $0.07-0.10 \%$ magnesium to meet their daily magnesium requirement (NRC, 2001). According to this, magnesium content of Calligonum polygonoides in our study is quite higher than the levels recommended for small ruminant in all months throughout the plant's development period. Moreover, magnesium content of the plant is also well above the maximum tolerable level that must be in the daily diet of small ruminant.

\section{Micro Minerals}

Amounts of micro minerals contained by phog during the 7-month research period from April to October are presented in Table 3. Statistical analysis revealed that only the iron content showed significant differences as to months and the average iron content of the shoots of the plant ranged between $99.73 \mathrm{ppm}$ and $190.43 \mathrm{ppm}$ during the 7-month research period. The highest iron content (190.43 ppm) was determined in April while the lowest iron content $(99.73 \mathrm{ppm})$ was detected in October and decreases in iron content were observed as the development period progressed (Table 3 ).

Table 3. Micro mineral contents of Calligonum polygonoides by months

\begin{tabular}{lcccc}
\hline Months & Fe $(\mathbf{p p m})$ & Cu $(\mathbf{p p m})$ & Zn $(\mathbf{p p m})$ & Mn $(\mathbf{p p m})$ \\
\hline April & $190.43 \mathrm{a}$ & 2.31 & 26.20 & 37.97 \\
May & $138.30 \mathrm{~b}$ & 2.35 & 25.90 & 41.37 \\
June & $125.66 \mathrm{bc}$ & 2.47 & 29.33 & 34.16 \\
July & $111.30 \mathrm{bc}$ & 2.67 & 28.03 & 35.60 \\
August & $115.16 \mathrm{bc}$ & 2.43 & 31.83 & 34.63 \\
September & $100.97 \mathrm{c}$ & 2.00 & 24.77 & 41.12 \\
October & $99.73 \mathrm{c}$ & 2.70 & 28.60 & 45.56 \\
\hline Mean & 125.93 & 2.42 & 27.85 & 38.63 \\
\hline P value and Significant & $10.63^{* *}$ & $1.34^{\mathrm{ns}}$ & $2.12^{\mathrm{ns}}$ & $1.11^{\mathrm{ns}}$ \\
\hline
\end{tabular}

$\mathrm{a}, \mathrm{b}$ and $\mathrm{c}$ Different letters in the same column indicate significant differences in the micro mineral contents. $* * \mathrm{P}$ values are very significant at $1 \%$ probability level, ns: no significant. 
Iron, which is generally found in the structure of chlorophyll, intensively participates in physiological activities in leaf cells, particularly in young cells (Jones et al., 1991; Kaya and Higgs, 2002). Because of this, iron content of the plants increase with the rapid growth at the beginning of the season, decrease with the slowing down of growth and become constant through the end of the season (Kacar, 1977). The animal body contains approximately 20-80 ppm iron (Kutlu et al., 2005). 90\% of the iron in the animal body exists together with proteins, the most important of which is hemoglobin. Therefore, iron plays an important role in the transportation of carbon dioxide to respiratory organs and the oxygen produced in these organs to the other organs. Iron is a required mineral for the activation of catalase, peroxidase and phenylalanine hydroxylase enzymes. Hemoglobin formation slows down and anemia seen in animals in the lack of iron in the animal body, as well as a slow-down in respiration and, as a consequence, a decline in energy production and loss of appetite (NRC, 2001; McDonald et al., 2011; Kutlu et al., 2005). An iron level of up to $500 \mathrm{ppm}$ in the daily diets of small ruminant is accepted as the tolerable level (NRC, 2005). It was also determined that feeds should contain 50-100 ppm iron in order to meet the daily requirements of the ruminants (NRC, 2001). The results of our research revealed that the iron content of Calligonum polygonoides can sufficiently provide for the daily iron requirements of small ruminant in all months throughout the plant's development.

Copper, zinc and manganese contents of phog did not change significantly according to months, and average copper, zinc and manganese contents during the 7-month development period were determined as $2.42 \mathrm{ppm}, 27.85$ ppm and $38.63 \mathrm{ppm}$, respectively (Table 3 ). The animal body contains approximately 1-5 ppm of copper, 10-50 ppm of zinc and 0.2-0.5 ppm manganese (Kutlu et al., 2005). Copper affects the absorption of iron and its efficiency in the tissues, and consequently, the synthesis of hemoglobin and oxygen metabolism. Copper is required for the formation of cytochrome oxidase and superoxide dismutase enzymes and of tracing pigment which is found in animal hair. Although zinc is found in every tissue of the animal body, it is mostly concentrated in the skins and hair of the animals. Zinc is also present in the structure of enzymes such as carbonic anhydrase, pancreatic carboxypeptidase, lactate dehydrogenase, alcohol dehydrogenase, alkaline phosphatase and thymidine kinase. It is an effective mineral in cell proliferation, nucleic acid metabolism, production, storage and secretion of hormones. Manganese, which is found in the animal body in very low amounts, is in the structure of hydrolase, kinase, argininase, pyruvate carboxylase and manganese superoxide dysmutase enzymes which have important functions in the animal body. (NRC, 2001; McDonald et al., 2011; Kutlu et al., 2005). In case of copper deficiency, animals may experience anemia, poor growth, weakening of bone development, and retardation of color formation in their hair. Zinc deficiency in animals may cause growth retardation, lack of appetite, retention in fertility, skin lesions and bone disorders. In case of manganese deficiency, deterioration of leg bones, growth retardation and fertility disorders can be seen in animals. (NRC, 2001; McDonald et al., 2011; Kutlu et al., 2005).

Maximum tolerable levels of copper, zinc and manganese for small ruminant are determined as $15 \mathrm{ppm}$, $300 \mathrm{ppm}$ and $2000 \mathrm{ppm}$, respectively (NRC, 2005). Moreover, ruminant feeds should contain at least 10-25 ppm of copper, $40.0 \mathrm{ppm}$ of zinc and 16-24 ppm manganese to meet the daily requirements of ruminants (NRC, 2001; ANAC, 2018). According to our results copper content of Calligonum polygonoides in all months of development is not sufficient to meet the daily requirements of small ruminant. Indeed, copper deficiency is a common situation in animals grazing in pastures (Judson et al., 1987). On the other hand, it was determined that zinc and manganese contents of Calligonum polygonoides are not in excess of their respective maximum tolerable levels and are sufficient to meet the daily requirements of small ruminant throughout the development period of the plant.

\section{CONCLUSION}

The $\mathrm{P}, \mathrm{K}, \mathrm{Ca}, \mathrm{Mg}, \mathrm{Na}$ and $\mathrm{Fe}$ contents of shoots of phog grown between April and October changed significantly as to months while no significant changes observed in $\mathrm{Cu}, \mathrm{Zn}$ and $\mathrm{Mn}$ contents. $\mathrm{Ca}, \mathrm{Na}, \mathrm{Mg}$ and $\mathrm{Fe}$ contents found to be high at the beginning of the development period in spring, however, it is observed to be decreasing with the progress of ripening period. Phosphorus and potassium contents are measured relatively higher during summer months when temperatures were higher. It is determined that the plant can meet with the daily $\mathrm{P}, \mathrm{K}, \mathrm{Ca}, \mathrm{Na}, \mathrm{Fe}, \mathrm{Zn}$ and $\mathrm{Mn}$ requirements of small ruminant throughout its 7-month development period. On the other hand, $\mathrm{Cu}$ content is not sufficient to meet the daily requirements of the animals while $\mathrm{Mg}$ content is found to be over the recommended level for ruminants.

\section{LITERATURE CITED}

Abdullah, M., R.A. Khan, S. Yaqoob and M. Ahmad. 2013. Mineral profile of browse species used as feed by grazing livestock in Cholistan Rangelands, Pakistan. Pak. J. Nutr. 12, 135-143.

Abdurahman, M., G. Sabirhazi, B. Liu, L. Yin and B. Pan. 2012. Comparison of five Calligonum species in tarım basin based on morphological and molecular data. EXCLI Journal 11:776-782.

Ahmad, K., M. Ashraf, Z.I. Khan and R.E. Valeem. 2008. Evaluation of macro-mineral concentrations of forages in relation to ruminants requirements: A Case Study in Soone Valley, Punjab. Pakistan. Pak. J. Bot. 40(1): 295-299.

Altıntas, A. 2013. Mineral materials. Disability-Overdose Diseases. Ankara University Lecture Notes on Biochemistry Department. 15-16 pp.

ANAC. 2018. Maximum Nutrient Values in Small Ruminant (Sheep and Goat) Feeds. Animal Nutrition Association of Canada.

Anonymous. 2018. Igdir Provincial Directorate of Meteorology. Igdir, Turkey.

Artan, G. and S. Temel. 2018. The effect of Ebu cehil (Calligonum polygonoides L.) shrub used as forage resource 
in Igdir-Aralı on some soil properties. Igdir International Conference on Multidisciplinary Studies 1: 242-249.

Aygun, C., C. Kara, H. Hanoglu Oral, I. Erdogan, A.K. Atalay and A.L. Sever. 2018. Macro and micro nutrient contents in seasonal (Spring, Summer, Fall) leaf samples of some shrub plants. Journal of Bahri Dagdas Crop Research 7 (1): 51-65.

Brandbyge, J. 1993. Polygonaceae. In K. Kubitzki, J.C. Rohwer and V. Bittrich (eds.). The families and genera of vascular plants, Springer-Verlag, Berlin.

Buxton, D.R. and S.L. Fales. 1994. Plant environment and quality. In: Forage Quality, Evaluation, and Utilization. (Ed: G.C. Fahey). ASA, CSSA, SSA, Wisconsin, pp: 1559199.

Chetri, K., D. Sanyal and L. Kar. 1999. Changes in nutrient element composition of guava leaves in relation to season, cultivar, direction of shoot and zone of leaf sampling. Commun. Soil Sci. Plant Anal. 30(1-2):121-128.

Cook, C.W. and L.E. Harris. 1977. Nutritive value of seasonal ranges. Utah Agr., Exp. Sta. Bul., 472 p.

De Baets, S., J. Poesen, G. Gyssels and A. Knapen. 2006. Effect of grass roots on the erodibility of top soils during concentratedflow. Geomorphology 76: 54-67.

Dokulgen, H. and S. Temel. 2015. Seasonal nutrient content changes of leaf and leaf + shoots in deciduous Christ's thorn (Palirus spina-christi Mill.). Journal of The Institute of Science and Technology 5(3): 57-65.

Eren, V. 2009. The effects of additional organic trace minerals on some production traits and determination of tissue accumulation and elimination levels in pregnant ewes and their newborn lambs. Adnan Menderes University Institute of Health Sciences. Department of Animal Nutrition and Nutritional Diseases, Aydin.

Gehlot, R.K. 2006. Nutritive value of some edible wild plants of the arid region of Rajasthan. J. Phytol. Res. 19(1): 147-148.

Ghazanfar, S., A. Latif, I.H. Mirza and M.A. Nadeem. 2011. Macro-minerals concentrations of major fodder tree leaves and shrubs of District Chakwal, Pakistan. Pak. J. Nutr. 10(5): 480-484.

Gokkus, A., A.O. Parlar, H. Baytekin and B.H. Hakyemez. 2013. Change of mineral composition of herbaceous species at the Mediterranean shrublands. Journal of Tekirdag Agricultural Faculty 10 (1): 1-10.

Govind, V.K., V. Kumar, R. Sharma, R.A. Sharma, S. Sharma, J.P. Singh and S. Kumar. 2012. Chemical and genetic diversity among some wild stands of Calligonum polygonoides (Polygonaceae) from the Thar Desert of Rajasthan. Rev. Biol. Trop. (Int. J. Trop. Biol. 60 (3): 10971108.

Greene, L.W., W.E. Pinchak and R.K. Heitschmidt. 1987. Seasonal dynamics of minerals of forages at the Texas Expertmental Ranch. J. Range Manag. 40: 502-506.

Gyssels, G., J. Poesen, E. Bochet and Y. Li. 2005. Impact of plant roots on the resistance of soils to erosion by water: a review. Prog. Phys. Geogr. 29: 189_217.

Hoveland, C.S. and W.G. Monson. 1980. Genetic and environmental effects on forage quality. In. "Crop Quality, Storage, and Utilization," American Society of Agronomy and Crop Science Society of America, Madison, WI, USA, pp. 139-168.

Jones Jr, J.B., B. Wolf and H.A. Mills. 1991. Plant analysis handbook: a practical sampling, preparation, analysis and interperation guide, Micro-Macro Publishing, Athens, GA.

Judson, G.J., I.W. Caple, J.P. Langlands and D.W. Peter. 1987. Mineral nutrition of grazing ruminants in southern Australia Temperate Pastures Their Production, Utilization and Management (Ed. J. L. Wheeler, C. J. Pearson and G. E. Robards). 377-385. Australian Wool Corporation/CSIRO: East Melbourne.
Kacar, B. 1972. Chemical analysis of soil and plant: II. Plant Analysis. Ankara University Faculty of Agriculture Publication No: 453, Ankara, 464 p.

Kacar, B. and A.V. Katkat. 1997. Phosphorus in agriculture. Bursa Commodity Exchange Publication No: 5, Uludag Univ. Printing house, Bursa.

Kaya, C. and D. Higgs. 2002. Improvements in the physiological and nutritional developments of tomato cultivars grown at high zinc by foliar application of phosphorus and iron. Journal of Plant Nutrition 25(9): 1881-1894.

Kerven, C., I.I. Alimaev, R. Behnke, G. Davidson, L. Franchois, N. Malmakov, E. Mathijs, A. Smailov, S. Temirbekov and I. Wright. 2004. Retraction and expansion of flock mobility in Central Asia: Costs and Consequences. African Journal of Range and Forage Science 21: 159-169.

Keskin, B., S. Temel, I.H. Y1lmaz and U. Simsek. 2016. The effect of halomorphic soil on $\mathrm{B}, \mathrm{Cu}, \mathrm{Mn}, \mathrm{Fe}$ and $\mathrm{Zn}$ content of some forage grasses. Sylwan 160(9):230-249.

Kutlu, H.R., M. Gorgulu and L.B. Celik. 2005. General animal feeding. Lecture notes. Cukurova University Faculty of Agriculture Department of Animal Science Department of Feed and Animal Nutrition, Adana.

Lambers, H., M.D. Cramer, M.W. Shane, M. Wouterlood, P. Poot and E.J. Veneklass. 2003. Structure and functioning of cluster roots and plant responses to phosphate deficiency. Plant and Soil 248: 9-19.

Liu, X.M., M.N. Zakaria, M.W. Islam, R. Radhakrishnan, A. Ismail, H.B. Chen, K. Chan and A. Al-Attas. 2001. Antiinflamatory and anti-ulcer activity of Calligonum comosum in rats. Fitoterapia 72: 487-491.

Mandal, L. 1997. Nutritive values of tree leaves of some tropical species for goats. Small Rumin. Res. 24: 95-105.

McDonald, P., R.A. Edwards, J.F.D. Greenhalgh, C.A. Morgan, L.A. Sinclair and R.G. Wilkinson. 2011. Animal nutrition. Seventh Edition. Publisher: Pearson.

McDowell, L.R. 1992. Minerals in animals and human nutrition. Department of Animal Science, University of Florida, Gainesille, Academic Press San Diego New York, USA.

McDowell, L.R. 2000. Vitamins in animal and human nutrition. Second Edition, Iowa State University Press, U.S.A.

Mertens, D. 2005a. AOAC official method 922.02. Plants Preparation of Laboratuary Sample. Official Methods of Analysis, 18th edn. Horwitz, w., and G.W. Latimer, (Eds). Chapter 3, pp1-2, AOAC-International Suite 500, 481. North Frederick Avenue, Gaitherburg, Maryland 20877-2417, USA.

Mertens, D. 2005b. AOAC official method 975.03. Metal in Plants and Pet Foods. Official Methods of Analysis, 18th edn. Horwitz, W., and G.W. Latimer, (Eds). Chapter 3, pp 34, AOAC-International Suite 500, 481. North Frederick Avenue, Gaitherburg, Maryland 20877-2417, USA.

NRC. 2001. Nutrient requirements of dairy cattle. Seventh Revised Edition, The National Academies Press, Washington, D.C., U.S.A.

NRC. 2005. Nutrient requirements of small ruminants (Sheep, Goats, Vervids, and new World Canelids). The National Academies Press, Washington, D.C., U.S.A.

Oktay, G. and S. Temel. 2015a. Determination of annual fodder value of Ebu cehil (Calligonum polygonoides L. ssp. comosum (L'Hér.)) shrub. Journal of Agricultural Faculty of Gaziosmanpasa University 32(1): 30-36.

Oktay, G. and S. Temel. 2015b. Determination of the growth patterns of Ebu cehil (Calligonum polygonoides L. ssp. comosum (L'Hér.)) shrub in terms of grazing management. Journal of Agricultural Faculty of Gaziosmanpasa University 32(2): $1-6$. 
Sher, Z., F. Hussain and M. Saleem. 2011. Macro-mineral status at three phenological stages of some range shrubs of gadoon hills, district Swabi, Khyber Pukhtunkhwa, Pakistan. Pak. J. Bot. 44(2): 711-716.

Spears, J.W. 1994. Minerals in forages. In: Fahey, G.C.J., Moser, L.E., Martens, D.R. and Collins, M., Eds., Forage Quality, Evaluation, and Utilization. ASA. CSSA. SSSA. Madison, 281-317 pp.

Tan, M. and S. Temel. 2012. Alternative feed crops. Ataturk University Agricultural Faculty Course Publications No: 246, 195-207 pp.

Temel, S. 2019. The determination of changes in monthly mineral contents of thorny saltworth (Noaea mucronata subsp. mucronata). Fresenius Environmental Bulletin 28(4): 2421-2425.

Temel, S., B. Keskin, U. Simsek and I.B. Yilmaz. 2016. The effect of soils having different salt content on mineral accumulations of some forage legume species. Fressenius Enviromental Bulletin 25(4): 1038-1050.

Temel, S. and A.E. Kir. 2015. Determination of grazing preferences of the small ruminants based on seasonal periods of some shrub and tree species. International Journal of Agriculture and Wildlife Science 1(1): 31-39.
Temel, S. and M. Tan. 2011. Fodder Values of shrub species in maquis in different altitudes and slope aspects. The Journal of Animal and Plant Sciences 21: 508-512.

Temel, S. and M. Surmen. 2018. Mineral content changes of some halophyte species evaluated as alternative forage crops for ruminants' nutrition. Fresenius Environmental Bulletin 27(11): 7340-7347.

Temel, S., M. Surmen and M. Tan. 2015. Effects of growth stages on the nutritive value of specific halophyte species in saline grasslands. The Journal of Animal and Plant Sciences 25(5): 1419-1428.

Temel, S. and I. Temel. 2018. Determination of some plant and yield characteristics with preference conditions in grazing of endemic Calligonum polygonoides L. ssp. comosum (L'Hér.) shrub for Turkey. Ataturk Univ., J. of the Agricultural Faculty 49(1): 7-13.

Underwood, E.J. and N.F. Suttle. 1999. The mineral nutrition of livestock. 3rd Ed. CABI Publishing, 614 p.

Vardar, Y. 1983. Plant Physiology Courses II. Growth and development events in plants. Ege Univ., the Science Faculty, Textbook No: 69, Izmir. 